\title{
Urban Housing Problems And Learning Among Off-Campus Students Of Nasarawa State University, Keffi
}

\author{
Martins Nyen Inyang \\ Department Of Sociology, \\ Faculty Of Social Sciences, Federal University Lafia \\ Frances Umari Ejue \\ Department Of Sociology, \\ Faculty Of Social Sciences, Federal University Lafia \\ Damian Kunza Agwadu \\ Department Of Sociology, \\ Faculty Of Social Sciences, Federal University Lafia
}

\begin{abstract}
Against theoretical evidence postulating a positive relationship between campus residency and collegiate outcomes, prior research has not established a causal link. This study undertook a socio-criminological analysis of Urban Housing problems and learning among off-campus students of Nasarawa State University, Keffi with particular reference to Angwan Lambu Area. The objective of this research was to evaluate the learning implications of off-campus accommodation students. The prevalence of social vices among students living off-campus and their preferences for off-campus accommodation was also examined. Social structure and Anomie theory was used as theoretical justification. The study employed the survey research design. A sample of 214 was drawn from a student population of 25380 using the questionnaire as data collection instrument. Data were collated, analyzed and presented through graphs and charts. Findings revealed that overcrowding, filth and slum-nieghborhoods are the poor living conditions of off-campus Angwan Lambu residences. Cultism, drug dealing and prostitution are some of the social vices common in the area. The study therefore calls on stakeholders by way of recommendations to invest more on students' accommodation. Security should also be strengthened around off-campus residences that are within the University neighborhood in order to monitor and contain any untoward behavior. The study concludes that learning can be improved and social vices resulting from, and affecting off-campus students can be curtailed where students are provided accommodation and a conducive learning environment by the University Authority either on-campus and/or through private estate developers.
\end{abstract}

Key words: Learning, off-campus accommodation, university, urban housing, students

\section{INTRODUCTION}

Provision of descent accommodation has a tremendous role in healthy living which can lead to improved productivity. Students and indeed learners all over the world require good accommodation to enable them properly assimilate classroom and laboratory interactions with their lecturers/instructors (Jabar, Yahya, Isnani \& Abu, 2012). The university owes its origin to the medieval cities of Bologna, Paris and Oxford around the year 1200 (Bender, 1988 in Owolabi, 2015). Owolabi has stated that throughout its history, the university has attracted large numbers of students of different nationalities and backgrounds. However, during the formative years, institutionally provided student accommodation did not exist and it was commonplace for students to hire a room or house from locals (Caldenby, 1994; Adelman, 
1969, Owolabi, 2015). In the Middle Ages in Europe, a town's population was rarely without a mix of students, which resulted in the problem of how and where to accommodate them. A glance at most tertiary institutions in Nigeria, especially the Universities, reveals that accommodation of students is severely overcrowded at on-campus systems (Ekejiuba, 2015). This is a direct impact of the high rate of applicants seeking university education in Nigeria (Ademola, Ogundipe \& Babatunde, 2014; Channels Television, 2017). As a quick fix approach, alternative accommodations in the neighborhoods became imperative, which by the way, are at very high rental cost, besides being scares (Abayomi \& Youdeowei, 2017). When they are available, the cost and security implication poses problems. These often lead to undesirable consequences (Ogeah \& Ajalaye, 2011).

In the light of difficulties in providing accommodation for students, most Universities resorted to off-campus accommodation policy. This policy became necessary in view of the growing number of those seeking tertiary education (Ogeah \& Ajalaye, 2011).

A deliberate alternative or off-campus accommodation policy seemed to have been articulated by most university administrators. This may not be unconnected with the assertion by Ekejiuba (2015) citing Ubong (2007) that inadequate accommodation to students in Nigerian universities is a reason the National Universities Commission (NUC) advised university authorities to consider students' villages close to the university (NUC, 2007). The NUC also requested the participation of the private sector in the provision of student hostels. Osewa (2017), Abayomi and Youdeowei (2017) contended that in almost all public higher institutions of learning, only the first year students are given automatic option of living on campus. This, the scholars noted, is to prepare the fresher-student on the task of getting acquainted with the academic environment of the university. However, Ekejiuba (2015) argued that in some exceptional cases, medical, post graduate students and sports men and women are given preference in allocation of accommodation. Scholars have cited a number of problems associated with off-campus accommodation, ranges from cost, distance, transportation to social isolation of students from recreational facilities provided by the institutions among others. The above mentioned challenges are the peripheral ones. The core problems of offcampus students in the opinion of Abayomi and Youdeowei (2017) are the ones that threaten both their lives and their academic pursuit. On the other hand, Aluede and Oniyama (2009), Information Parlour (2017) in their separate studies concluded that off-campus students often time are associated with social vices some of which include stealing, armed robbery, drug abuse, cultism, prostitution and formation of gang groups.

Among the myriad of factors affecting academic performance of undergraduates in Nigeria is the issue of adequate accommodation (Akingbohugbe \& Akinluyi, 2012). A glance at most Nigerian public Universities show that students' accommodation is severely overcrowded. In 2006 The National Universities Commission (NUC) alarmed that findings from the presidential visitation panel that looked into the operations of all federal universities between 1999 and 2003 indicated that academic and physical facilities at the universities were in deplorable states (Babatope, 2010). The situation is not unexpected, as according to Dober (1963) cited in Owolabi (2015), on-campus accommodation was treated as educational, rather than a housing need of students by governments, hence universities were mandated to cover wide catchment areas. This implied that the link between learning and conducive residence was not taken into consideration by the university establishment. In support of this position, Ijaiya (2001) argued that there is a direct relationship between the quality of education and infrastructural facilities available to the Nigerian child. To further buttress the point, Adeyemi and Igbinewaka (2000) in Babatope (2010) affirmed that the mismatch between growing enrolment and provision of facilities ultimately results in overcrowding. This scenario has reached crisis situation at 
Nasarawa State University, Keffi where most students live are now compelled to source accommodation off-campus. The high demand for residential accommodation by both the students and other categories of citizens has affected availability and cost of accommodation in Keffi town.

This situation has further been aggravated by the absence of affordable and safe alternative housing in the neighborhoods of the university. The University's response to the problem to arrest the situation is largely inadequate. This is so due to the neglect of the Built-Operate and Transfer (BOT) Policy of the National Universities Commission (NUC) (Abdulhafeez, 2014). Ibrahim Abdulhafeez's findings show that Inconsistencies in Government policies account for the failure of the BOT policy of the NUC.

Okebukola (2006) addressed the plight of university students in Nigeria as one of massive explosion in student enrolment, increasing numbers of prospective new entrants in the face of inadequate and obsolete infrastructure and equipment. Elsewhere, Zotorvie (2017) submitted that key among the factors that influence the choice of residence by students include proximity to lecture halls, spacious and well ventilated rooms; calm and peaceful environment, availability of study area, accommodation cost, and availability of electricity and water supply. These factors and facilities are not only requisite, but sine qua non for the achievement of the objectives of the university. This apparently results in the search for alternative accommodation by students at the Nasarawa State University, Keffi (NSUK). Learning becomes affected as less time is invested to study due to the array of challenges. The result of this is felt in the quality of our graduates which ultimately leads to inefficient manpower and productivity for the nation

Arising from these challenges, the study investigated the accommodation problem particularly at Angwan Lambu, a neighborhood village around the university where students usually reside due to its proximity to lecture halls.

\section{RESEARCH OBJECTIVES}

The study set out to achieve the following objectives

I. To ascertain the learning implications of urban housing among off-campus students at Nasarawa State University, Keffi

II. To determine what types of social vices are common among students living off-campus at Nasarawa State University, Keffi

III. To investigate students' preferences of residential accommodation at Nasarawa State University, Keffi

\section{LITERATURE REVIEW}

\section{Conceptualizing Urban Housing, learning and off-campus students}

Schudde (2011) found out that there exist a strong probability that students' residency on campus impacts greatly on their learning outcomes, in addition to ensuring a continued enrollment into the subsequent years of study. Amole (1997) in Agbola et al (2001) revealed that many educators holds the belief that there should be close proximity between the living (accommodation) and learning (campus) environment, in order for goal attainment of the university. Assessing the goals of the university, Hornby (2004:1309) stated that it is an institution at the highest level of education were one can study for a degree or do research. For Rundell et al (2005:803), it is an educational institution where students study for degrees and where academic research is done. 
The concept of the university community is for all the members of such community to live together in a given geographical area. Such an area is popularly known as the Campus. This makes for rigorous academic activities which brings the realization of the goals (Agbola et al 2001). It is save to argue that the collegiate system of the Oxbridge where both students and the faculty shared common life was premised on the concept o the university community. It was then felt that different home backgrounds could be compensated in the fusion of living and learning through which common standards of culture and citizenship could be transmitted.

\section{Nature of off-campus accommodation}

Although Owolabi (2015) argued that off-campus accommodation was the earliest form of student accommodation, the concept crept into the Nigerian university system following the Ogundeko Commission of 1977 on BOT (Adesina, 1988). Based on its findings that they exists wide disparity between student population and available student accommodation, the Commission recommended the development of off-campus accommodation. Ekejiuba (2015) summarized the quest for university education as a privileged that hitherto was for the upper class but now open to all; thus hostel accommodation should receive the attention it deserve. However, available data show a wide neglect of this consideration, giving for the regulatory body, the NUC (Abdulhafeez, 2014), to suggest a Public Private Partnership (PPP) among stakeholders on the basis of the BOT in order to meet this residential challenge to students. Because there is a reluctance on the part of university administrators to source alternative accommodation for their new enrollees who often times outnumber available spaces (Ademola et al, 2014) students often look for cheap accommodation within the neighborhood of the university on rental basis.

Similarly, satellite villages built by States and Federal government in form of low cost housing have provided accommodation for off-campus students of many universities in Nigeria (NUC 2007, Ekejiuba 2015).

To provide off-campus accommodation for students most universities in Nigeria and indeed the world over resorted to the acquisition and conversion of properties within the city into hostels. Amole (1997) stated that the private lodging system acquired as hostels failed woefully due to inadequate operating policies. Agbola, Olaturbara, and Alabi (2001) for instance observed that the housing productivity theory which states that a good or decent housing unit with all necessary ancillary services and which is located in an environment that is conducive, is capable of increasing the productivity of its tenants. This underscores the reason some well-to-do parents prefer private houses off-campus without minding the cost, as against students from underprivileged homes whose off-campus residences are usually marked by overcrowded, dilapidated structures antithetical to the productivity theory.

\section{Nasarawa State University Students' Hostel Accommodation and the recourse to Angwan Lambu}

The Oxbridge institutions of the United Kingdom provided accommodation for students which include a place to eat and socialized with fellow students as well as academic supervisors. The Nigerian universities established in the 1960s and early 1970s modeled their campuses in the same manner providing halls of residence with recreational facilities. Anyone who attended the first generation Nigerian universities of Ahmadu Bello, Ibadan, Nsukka and Ife, where accommodation and recreational facilities were provided to students and lecturers within the campus would notice a sharp contrast with the current situation.

Students, who live off campus, do not often enjoy the benefit associated with on-campus student live such as games, cultural dances, understanding social behaviours and cultural 
norms of other people when they share university halls. Vander and Silversten in Agbola et al (2001) indicated that the formation of social group coincided with floor levels.

Earlier, Holahan and Wilcox (1978) made an assertion that the physical form of the student accommodation significantly affected the emerging degree of commitment by the students towards each other, the pattern of interaction, emotional support and the level of involvement in organizational functioning. This agrees with the position of Amoge (2008) in Ekejiuba (2015) who argued that hostel or halls of residence are sine qua non for effective guidance assessment of learning. Since majority of students live off campus, there is a phenomenal decline in students' campus life in most, if not all Nigerian universities today.

\section{Nature of off-campus accommodation}

As a result of the disparity between student population and available student accommodation, most universities considered providing alternative accommodation to students by negotiating with private developers to satisfy this need on rental basis. This also informed the acquisition and conversion of properties within the city into hostels.

Similarly, satellite villages build by state and federal governments in form of low cost housing have provided accommodation for off-campus students of many universities in Nigeria. However, Amole (1997) has argued that the private lodging system acquired as hostels failed woefully due to inadequate operating policies. It is safe to say that it is not in all instances that private lodgment failed, for instance, Agbola et al (2001) supports the housing productivity theory noting that a good housing unit within the neighbourhood of the university environment is capable of increasing the productivity of its tenants. This, perhaps, influences the preferences of private residential accommodation off-campus by parents/guardians who can afford it.

\section{Social vices and academic activities in the Nigerian Universities}

Studies have shown that social vices do emanate from off-campus accommodation and they negatively affect students' academic activities. The effects are centered on learning, social behaviour, cultism, drug addiction, prostitution, besides taking a toll on their finances and the general security risk to the student community.

Learning is a knowledge that one gets from reading and studying. Inyang (2017) identified the features of education for the student to include learning to be, learning to learn, learning to do and learning to live together. Off-campus residences for students appear to put a clog on the achievement of these learning outcomes. This is the opinion of Akindele (1996) who observed that off-campus students are subjected to different sorts of disturbances including undue interferences to gossips from their co-tenants. He further opined that they are often victims of unbearable loud noises, deafening music from endless street parties organized by co-tenants, neighbors, beer parlours, and music stores. All these have negative effect on learning. Most offcampus accommodations are not suitable for students' habitation, the effect of which retard learning by off-campus students. (Agbola et al, 2001).

University accommodations are usually built with the sole aim of increasing student's productivity through closeness to all activity areas and also for generating academic community spirit (Adelaide, Anyobodeh \& Abban, 2016). This is more so when all study groups are housed in one environment instead of off-campus, the time taken to commute or trek from the off-campus village and neighborhood could affect learning period as well as put some strains on the learner. 
Off-campus accommodation is bedeviled with lots of social misdemeanors. Scholars such as Prusok and Walsh (1964), Heilwel (1973) argued that off-campus students consider themselves as marginal members of their institutions, having little or no participation in social and recreational activities. They tend to be socially isolated. Students from various backgrounds when brought together to interact and live in the same physical environment have significant impact on the social life and social organization of resident students; this, the study found out, usually eludes the Students leaving off-campus. Besides, off-campus students are not likely to enjoy the communal teaching, social and recreational facilities and may not very likely form different social structures and organizations which are common features of on-campus live. In the place of these social activities, anti-social behaviours such as stealing, cultism, gang groups, armed robbery and prostitution are common features mostly associated with off-campus students. This is a common feature of slum neighbourhoods (Cohen 1955, Carrabine, Cox, Lee, Plummer \& South 2008, Iwerimie-Jaja, 2012). For instance, secret cultism which has permeated the Nigerian university system fetters deeply among both off and on campus students. However, as Smah (2001) noted, because cultists leave in constant fear, offcampus residences becomes a save heaven for their dastardly acts.

\section{Transportation}

Oyesiku (1994) shares his views that city development must be seen in the efficient operation of a functional transport system. Angwan Lambu is a student village situated close to the Nasarawa State University, thus shares the burden of a deplorable transport system. However, the university management and Student Unions have in the past attempted to cushion the effect by making available commuter buses to ply routes leading to important satellite villages and administrative halls of the institution. As student enrolment increases without a correspondent increase in bus services, the off-campus students had to feel the pressures which include having to pay higher fares. Earlier, Smah (2001) argued that the difficulty in campus transport interconnectivity lies in the affordability by students. This leaves the student with no option but to trek long distances to lectures, which impact negatively on their learning (Agbola et al, 2001).

\section{Security}

These are the activities involved in protecting a person against attack or any danger. Squatting has become a form of providing accommodation at campuses. It is a situation where a bed space/room that was meant for two occupants may be occupied by about four or more students due to inadequate accommodation. However squatting is not peculiar to on-campus residence alone but practiced among off-campus students. Lose of personal effects and attacks from suspected cult gangs are some of the security risk inherent in such a situation. Agbola et al (2001) indicated that security forms a critical item in student's choice of place of residence. Off-campus students seldom benefit from the security apparatus of the university, which provides maximal security coverage within its campus area of jurisdiction.

Many vices have been recorded over time as resultant effect of off-campus accommodation; Cohabitation, drug addiction, poor academic performance, school drop-out and unwanted pregnancies, with some resulting in near fatal or fatal abortions among others.

\section{SCOPE, DESCRIPTION OF THE STUDY AREA}

This study was carried out in the Nasarawa State University Keffi. The university established under the Nasarawa State University Establishment Law No. 2 of 2001, came on stream in February 2002. With a mission to produce an equipped manpower needs for the state and Nigeria (http://www.google.com/a/nsuk.edu.ng, 2017). 
The university currently runs seven faculties to include Faculty of Administration, Agriculture, Arts, Law, Education, Natural and Applied Sciences and Social Sciences. The School of Post Graduate Studies (SPGS) was also established by the university to train graduate students and upon satisfactory completion of various courses of studies, award Post Graduate Diplomas, Masters Degrees and PhD Degrees in various academic disciplines (http://www.google.com/a/nsuk.edu.ng, 2017).

With a robust registered population of twenty five thousand three hundred and eighty $(25,380)$ students, made up of six thousand five hundred and twenty seven $(6,527)$ post graduate students and eighteen thousand eight hundred and fifty three $(18,853)$ undergraduate students, the university provides a requisite manpower needs of Nasarawa state, Nigeria and the global community at large (ICT Unit, 2017., Academic Affairs Division, 2017., Dean, SPGS, 2017). This is obvious from the array of student enrollment spread across all the states of the federation beyond Angwan Lambu is an off-campus student suburb, situated about a kilometer away from the NSUK main gate. Angwan Lambu is a coinage of two words from the Hausa language. Angwan refers to a settlement, hamlet or a suburb, whereas Lambu is the Hausa word for garden or vegetative area. Planting of vegetables in the area was purely on land-grabbing basis, and was done by locals who found the uninhabited/undeveloped area fertile for their small holding farming. Vegetable farming was soon replaced by makeshift shanty structures at the commencement of the NSUK, by those who saw to it that they could make quick rental profit from students who may not be accommodated in the few available hostels on campus.

Angwan Lambu caught the interest of the researchers due to its popular appeal among students sourcing off-campus accommodation. This study revealed that the appeal is due largely to its proximity to the university as well as its rental cost implication. There are other areas within Keffi town and environs such as High Court Area, Road Safety, BCG, etc, where students also secure accommodation. However, only affluent students and a few squatters do patronize accommodation in the mentioned areas.

The survey included both on-campus and off-campus students. Academic staff also constituted the respondents. Non-student residents within the area of study were carefully excluded.

This study was however limited to samples drawn from students currently studying at the university. It did not consider previous years but only limited to students of 2017/2018 academic session.

\section{Social structure and Anomie theory of R.K Merton}

\section{THEORETICAL FRAMEWORK}

Social structure and Anomie theory originated with Robert K. Merton (1938). The nature of social reality in Nigeria today and indeed the world over is so complex that every social phenomenon is subjected to various analysis and interpretations depending on which of the theoretical realm one falls. It is on this note that the social structure theory is being considered in order to explain the forms, characteristics and variations of criminality that are associated with off-campus accommodation in Nigerian universities. This theory explains that criminality is fundamentally related to the social system. The theory argues that crime is fundamentally related to the social system. Merton asserts that when social regulations are weak or broken, the controlling influence of society on the individual to conform to rules and regulations is no more effective. And because rules and regulations are broken, individuals are lawlessly free to adopt deregulatory methods to social life. To this extent, various adaptations are bound to result. Also that society enjoins individuals to strive to institutional goals but access to the 
institutional goals is unequal (Igbo, 2008). Explaining off-campus accommodation using the above theory, it is clear that off-campus accommodation is an alternative to on-campus accommodation, because access to on-campus accommodation is unequally distributed as argued by Merton.

When social regulations are weak or broken as in the case with Off-campus, students engage in deviant and criminal act because laws guarding off-campus are weak or are normless as argued by Merton. Off-campus students therefore engage in criminal act because the controlling influence of society on off-campus students are weak; as such adopt deregulatory methods to social life such as prostitution, gang groups, cultism etc.

Arguing further on the anti-social behaviours among off-campus students using the above theory, the paper states that cultism in the universities especially among off-campus residents is a product of the imbalances in our socio-economic and political structure. Supporting this line of argument, Umar (2008) contended that until the structural imbalances are practically addressed, the menace of cultism with bad effects will continue to persist. Assessing the menace of off-campus student accommodation, using social climate theory, Moore (1976) argued that learning outcomes are affected by the environment where studies take place. He argued further that some behavioural attributes of students like study habit can surely be applied to practical problems that occur in the hostels. Mark (2014) in Amoge (2015) reiterated that learning process is thus soothe or broken by the types of their hostel's environment.

Off-campus accommodation secured by students is prone to various social vices particularly cultism and prostitution. These negate the conclusion of Ubong (2007) who states that social interaction and effective academic study instrumental in fostering a successful university experience. Because of the exposure of off-campus students to the local communities without any parental or faculty control, most students usually fall prey to activities of cultists or other gangs. Off-campus accommodation that harbors all sorts of people with such social vices poses problem to the students, particularly the students accommodated at Angwan Lambu in Keffi. This no doubt compelled Yusuff (2011) to note that residence halls or a hostel remains the traditional housing option for students in the university.

\section{METHODOLOGY}

The study adopted the survey research design which allows for representative samples in the collection of data. Respondents involved in the research were from the ages of 18 years and above. This study employed the Survey Software Calculator (2014). A sample size of 214 respondents was selected via simple random (balloting) sampling method (Michael et al, 2016). Purposive sampling technique was then employed in the selection of the actual sample respondents for the study.

Four points Likert scale questionnaire was designed, which were used to answer the research questions. Part I of the questionnaire focused on the demographic data of respondents. Part II covers the objectives of the study, which were used to ascertain the correlation among variables. It had 10 items on the determinants of student accommodation, Urban Housing Problems and Learning among Off-campus Students of Nasarawa State University, Keffi.

We adopted the following as response pattern to the items: Strongly Agreed (SA), =4; Agreed $(A),=3$, Strongly Disagree (SD) $=2$ and Disagree (D) $=1$. The average of these points is thus $4+3+2+1=\frac{10}{4}=2 \cdot 50$. The questionnaire was considered expedient in the study due to its extent of subject matter coverage and impersonality of the respondents. 


\section{RESULTS AND DISCUSSION}

\section{Chart I: Category of Respondents}

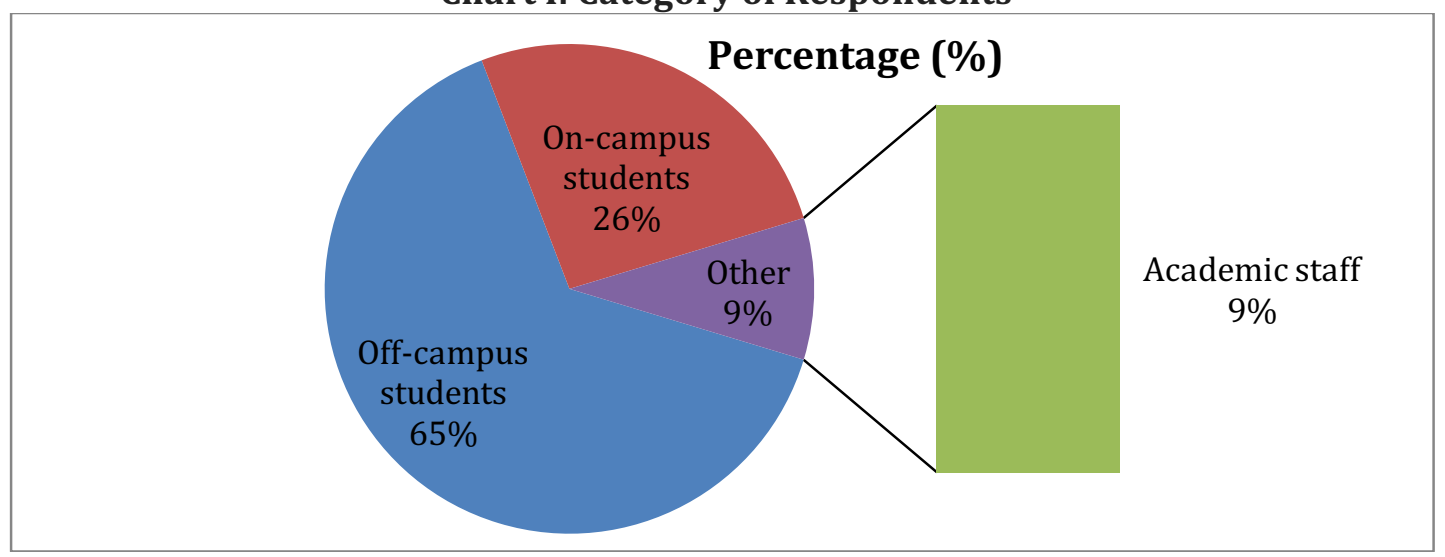

Source: Authors' field data, 2017

Results show the category of respondents to include academic staff (9\%), On-campus students $(26 \%)$ and Off-campus student (65\%) respectively. From the analysis, it could be seen that offcampus students were the most respondents. This is not too surprising since the study was basically targeted at them.

Chart 2: Socio-Demographic information of respondents

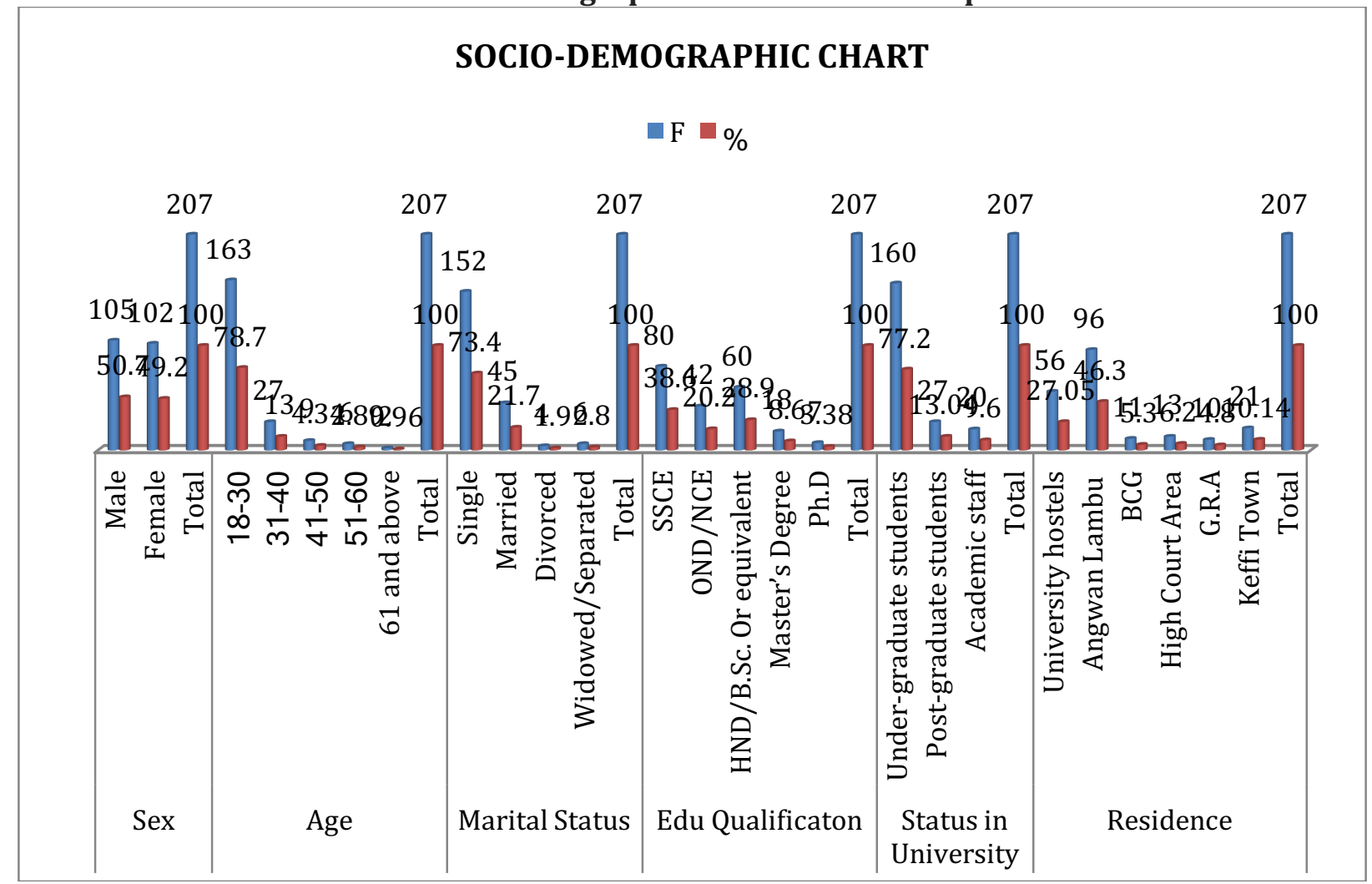

Source: Authors' field data, 2017

The chart 2 above is an analysis of the socio-demographic characteristics of respondents. More males participated in the survey (50.74\%) participants age $18-30$ made up $78.7 \%$, which means the active youth population constituted a majority of those sampled. Under marital status, the single respondents totaled 73.4\%, leaving the married, divorced and widowed/separated with $21.7 \%, 1.9 \%$ and $2.8 \%$ respectively. Sampled respondents also indicated that 38.6\% had SSCE, 20.2\% had OND/NCE and 28.9\% had either HND, B.Sc. or its 
equivalent. Those with Masters and $\mathrm{PhD}$. were $8.6 \%$ and 3.38\% respectively. Respondents' status in the university indicates that undergraduates were the most sampled, constituting about $77.2 \%$. With reference to their residence, $27.05 \%$ leave On-campus, $46.3 \%$ at Angwan Lambu, $5.3 \%$ at BGC, $6.2 \%$ at High Court Area, $4.2 \%$ at GRA and $10.14 \%$ Keffi Town respectively

\section{Chart 3: Off-campus accommodation of Respondents}

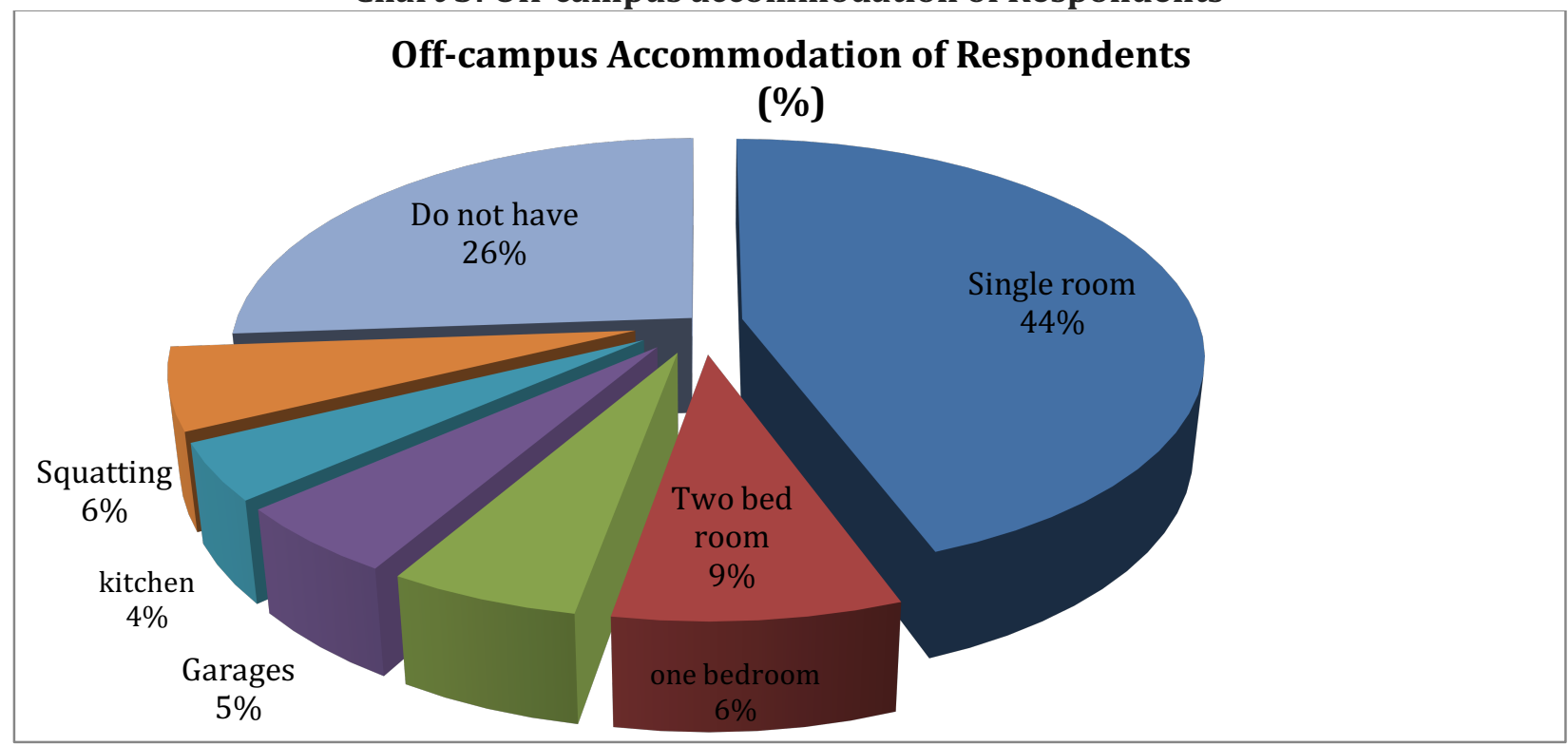

Source: Authors' field data, 2017

Analyzing the nature of Off-campus accommodation, information on Chart 3 indicates that those who occupy single rooms were in the majority (44\%). The analysis further indicates that those 'who do not have' (26\%) were those who live On-campus. Others are squatting (6\%), kitchens (4\%), garages (5\%), one bedroom (6\%) and two bedrooms (9\%) respectively. Those that are squatting (6\%) are either Freshers or do not have enough money to secure accommodation for themselves, hence they resort to squat awhile with a "willing" host. Some landlords/landladies have converted their kitchens and garages into living rooms, thereby making money via renting them out to students

\section{Chart 4: Reasons for Preference of Off-campus Accommodation}

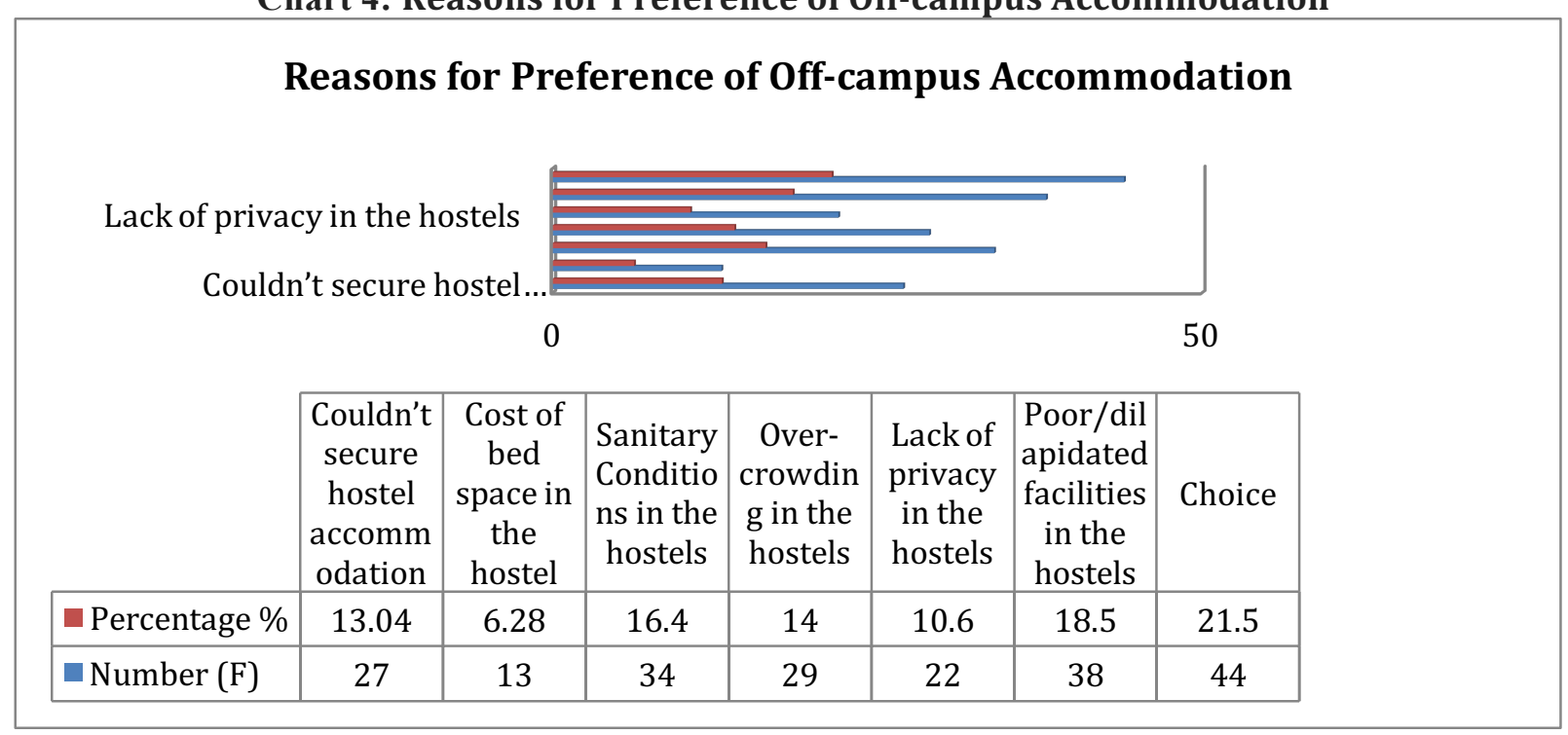

Source: Authors' field data, 2017 
Chart 4 presents analysis of respondents' preferences to their accommodation. While it is obvious that Choice influences more respondents $(21.5 \%)$, other factors such as inability to secure on-campus accommodation (13.04\%), cost of bedspace (6.28\%), sanitary condition $(16.4 \%)$, overcrowding $(14 \%)$, privacy $(10.6 \%)$ and poor state of hostel facilities $(18.5 \%)$ respectively collectively contributed more (78.5\%) to their preferences. Babatope (2010) had argued that due to poor maintenance culture, campus facilities including those of hostels are in dilapidated states. The scholar maintained that sustenance of campus facilities largely depends on improved maintenance culture. Adelaide et al (2016) revealed that among the reasons students would prefer alternative accommodation to hostels is the problem of inadequate infrastructure, overcrowding and sanitation challenges. The implication is that priority should be given to upgrade of hostel facilities on our campuses, since they largely influence students' desire to seek campus accommodation.

Chart 5: Cost of your Annual Rent ( $\mathrm{N}$ 00: 00K)

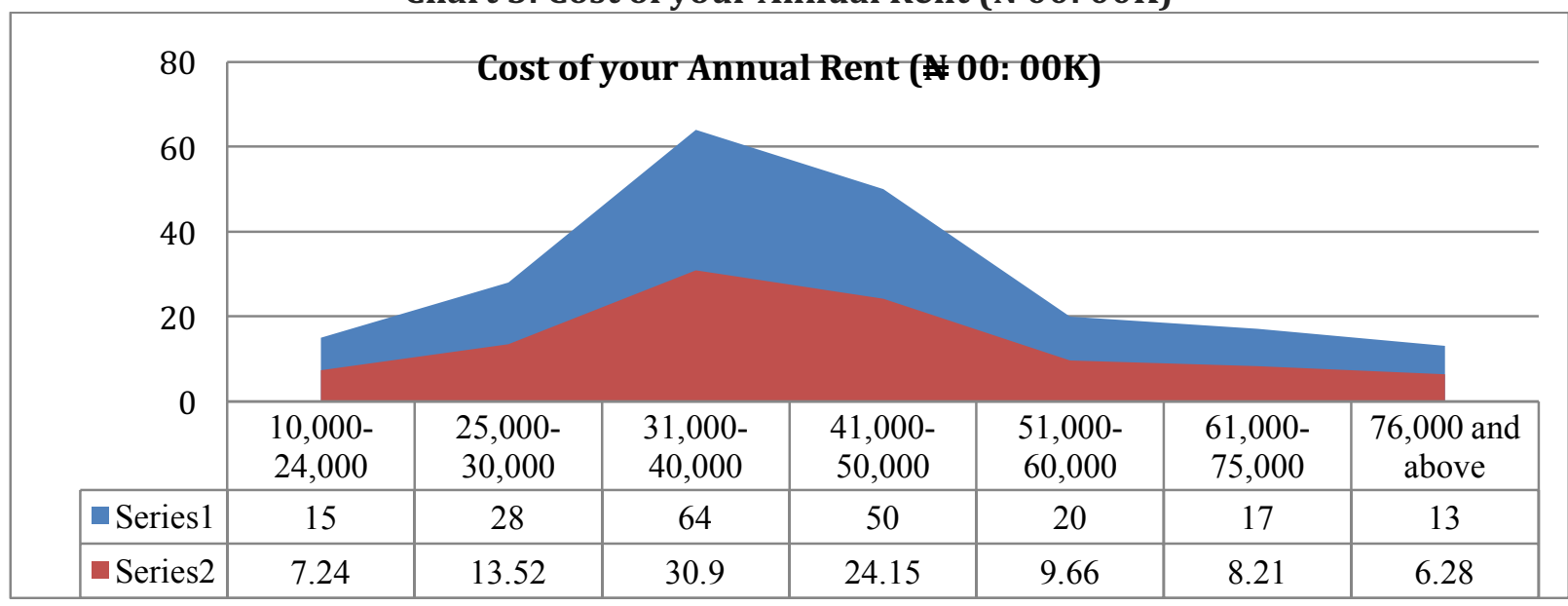

Source: Authors' field data, 2017

The data on chart 5 above is a survey on the respondents' estimation of the annual rent within the range of $\# 10,000.00$ up to $\# 76,000.00$ and above. Analysis indicates that a higher percentage of the student respondents (68.57\%) secure their accommodation at a cost between $\$ 25,000-\$ 50,000.00$ only. The analyses on the cost-implication also show the huge burden parents and guardians have to borne in order to secure accommodation for their wards in the university. This therefore means that there is a nexus between cost of university education and school enrollment, given the economic downturn in the country. Zotorvie (2017) found out from the study of Khozaei, Ayub, Hassan and Khozaei, (2010) that rental rates among other factors constitute students' preferences of off-campus accommodation. It is also instructive to state that high cost of accommodation constitutes a huge reason for poor academic performance among off-campus students; since some of them would have to spend longer time hustling for extra income to meet their financial needs. Respondents whose accommodation cost ranges between $\$ 61,000$ - \$75, 000 and $\$ 76,000$ and above were mostly academics. This is however understandable since most academics are with their families, and would ideally require larger accommodation than students without families. 
Chart 6: No of Students living together

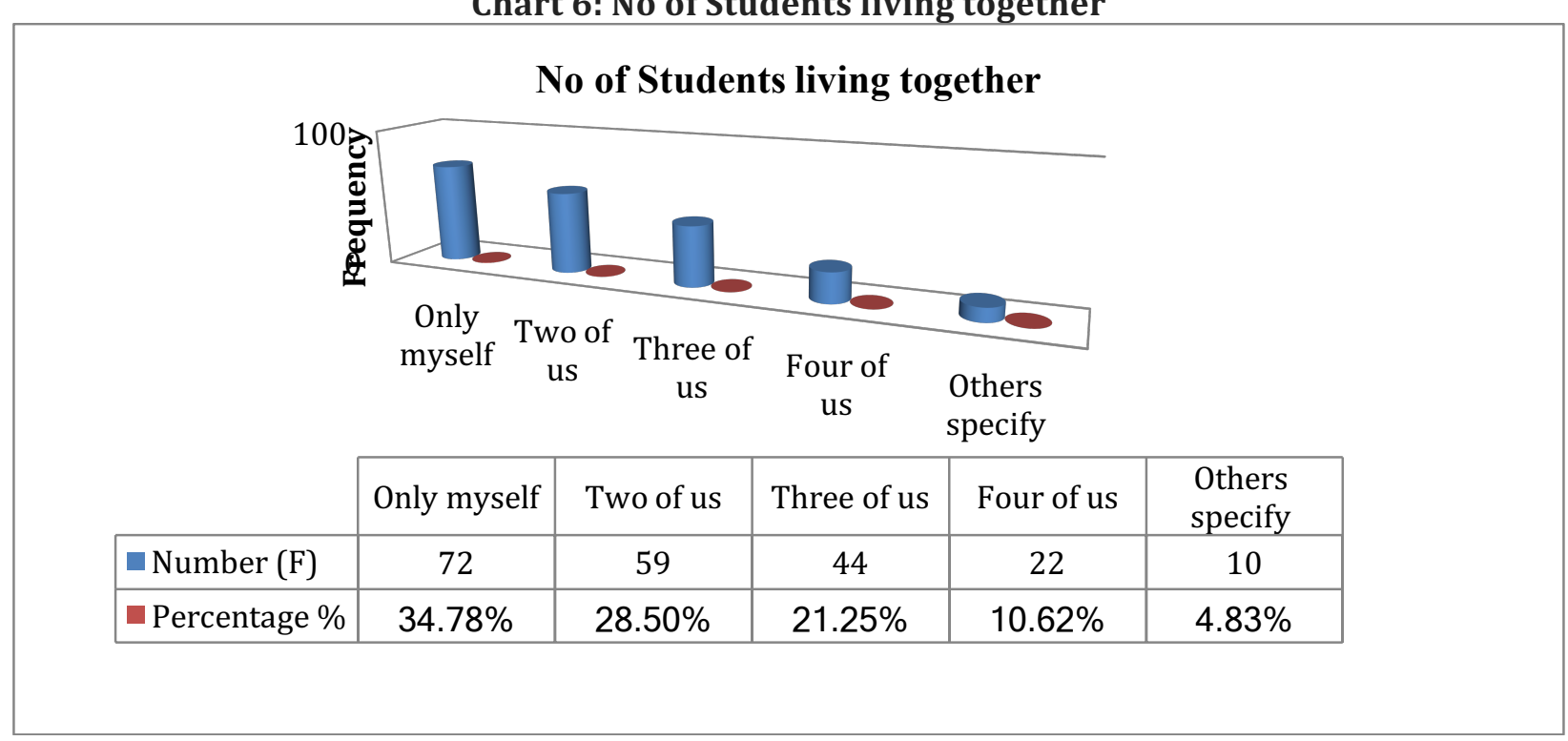

\section{Source: Authors' field data, 2017}

From the Chart 6 above, the study found that more students $(60.37 \%)$ share residences. This is because they often contribute resources (money) to secure the accommodation, thereby sharing the cost-implication among them. These shared accommodations also have implications on students' academic performance and their indulgence in social vices. : Auwal (2014) reiterated that cohabitation among other factors contribute largely to campus vices.

\section{Chart 7: Common vices among off-campus students}

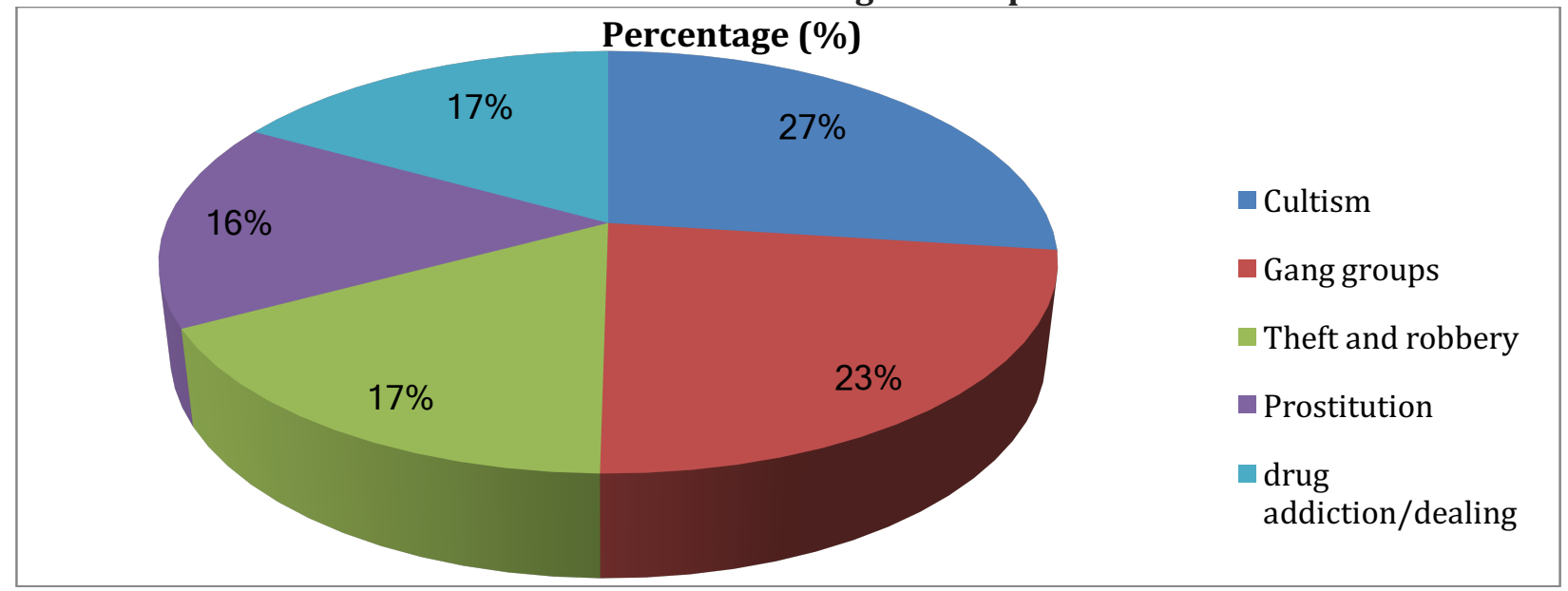

Source: Authors' field data, 2017

Cultism (27\%), gang groups (23\%), theft and robbery $(17 \%)$, prostitution $(16 \%)$ and drug addiction/dealing (17\%) are the identified social vices prevalent among off-campus residents. Further analysis of chart 7 above indicates that cultism and gang groups (50\%) constituted the two most frequently occurring vices noticeable in any given off-campus residences.

\section{Research Findings}

Arising from the analysis of data, the following findings were arrived at.

Youth whose ages range from 21-30 had the greater proportion of the participants, they constituted $62.24 \%$. Majority of the participants (57.14\%) are SSCE and OND/NCE holders. Undergraduate students constitute the major participants with $81.63 \%$. 
The satellite areas within the neighborhood of the university seemed to have fair representative rate of students residing in them. Angwan Lambu, the study area, however, has the highest number of 58 representing $29.24 \%$. The research also revealed that as much as $52.04 \%$ of the participants indicated their residence has only one room.

It was further discovered that some of the respondents live in garages and kitchens (9\%) which were converted to living rooms, demonstrating the extent of hardship off-campus students normally encounter.

Despite the benefits of on-campus accommodation, Zotorvie (2017), 35.71\% of the participants would rather prefer off-campus because of over-crowding in the halls or hostels (Babatope, 2010).

The study revealed that some social vices such as cultism (30.61\%), theft and robbery (20.41\%), abound among off-campus students. These would have an effect on the productivity and learning by the students. The long run effect is better imagined than can be appreciated.

Result obtained from this study has far reaching implications if the university authority and indeed the government of the day who need to develop its human capacity want to advance. It must look into the accommodation of students in tertiary institutions.

Education, we have been often reminded, is that singular factor that can bring us out of poverty (Inyang, 2017). Half baked knowledge can lead us to nothing. It would continue to see us poor. Ajegena (2000) once contended that poverty is with us, it is in us, and will continue to be with us for a long time if we decide to play with our educational system especially the accommodation of our students, where they have to retire to, after long hours of study

\section{RECOMMENDATIONS}

Based on the findings of this study, the following recommendations have been proffered.

Government, university authorities and other stakeholders should take the issue of students' accommodation in tertiary institutions seriously. This study recommends that at least $80 \%$ of students should be accommodated on-campus in order for the goals of the institutions to be achieved.

Estate developers should be encouraged to invest more in the provision of campus accommodation for tertiary students so the nation can reap from the benefit accruable there from.

Visitors to the universities and other higher institutions should increase their capital grants to these institutions to enable them invest in building residential halls or hostels for their teeming students population.

The study also recommends that parents and guardians should devote more attention to the protection of their children and wards against campus vices in view of the negative outcomes Security agencies should be properly trained and posted to areas of concentration by these offcampus students in order to curtail social vices that may manifest.

While students are admonished to regularly engage in environmental sanitation of their surroundings, the authorities are advised to cultivate a feedback mechanism within the areas 
where students live so as to enable leadership feel the pulse of students and make positive corrections where needed.

\section{References}

Abayomi, A., \& Youdeowei, T. (2015). Students, varsities hostel and shylock landlords in the Vanguard. https://www.vanguardngr.com/ Retrieved November 3, 2017.

Abdulhafeez , A. (2014). An Investigation into Build Operate and Transfer in the provision of hostels in Nigerian Federal Universities. A Thesis Submitted to School of Postgraduate Studies Ahmadu Bello University, Zaria

Adelaide, S. K., Anyobodeh, R. \& Abban, G. (2016). An Assessment of the Accommodation Challenges Faced By Students of Takoradi Polytechnic. International Journal of Novel Research in Marketing Management and Economics 3(1), pp 64-72. Available at: www.noveltyjournals.com

Adelman, H. (1969). The Beds of Academe. Toronto: James Lewis \& Samuel Ltd.

Ademola, E.O., Ogundipe, A.T. \& Babatunde, W.T. (2014). Students' Enrolment into Tertiary Institutions in Nigeria: the Influence of the Founder's Reputation - A case study. Computing, Information Systems, Development Informatics \& Allied Research Journal 5(3). September 2014. www.cisdijournal.net. Accessed November 3, 2017.

Adeyemi, J.K., Igbinewaka, V.O. (2000). "Sitting Space Utilization in Nigerian Universities: A case study of the University of Benin”. J. Teach. Educ. Teach. 4(1): 12-23. Retrieved from http://www.academicjournals.org/ November 7, 2017.

Agbola T, Olaturbara, C.O. \& Alabi, M. (2001). Students on Campus Housing at Bursting point: A case study of the University of Ibadan French institute for research in Africa. Occasional Publication No.4 Ibadan.

Awotunde, P.O. \& Ugoduluwa, C.A. (2004). Research method in education: Feb. Anieh Pub. Jos.

Akindele U. (1996) Accommodation: Tales, Tears and Tolls. Ogun poly echo 15(1) 11-13

Akingbohugbe, D.O. \& Akinluyi, M. (2012). Resident perception of off-campus students' housing performance in Ili-Ife, Nigeria. Journal of Environmental and Earth Sciences. 2(7). ISSN 2224-3216 (paper) ISSN 2225-0948 (online)

Aluede, R., Oniyama, O.A. \& Hope, O. (2009). Secret cults in tertiary institutions in Nigeria: an appraisal. Alabama: Project Innovation: A Report. 43 (1) (ISSN: 0146-3934).

Amole 0.0. (1977). An evaluation of student's residential facilities in some Nigerian Universities. Ile-Ife. Obafemi Awolowo University.

Auwal, A.M. (2014) Curbing campus Vices. In The Nation News Paper August 28. Sourced online November 3, 2017

Babatope, B.A. (2010). Problems of facilities in South-West Nigerian universities and the way forward. Journal of Education Administration and Policy Studies 2 (2), pp. 039-043. Retrieved November 7, 2017 from http://www.academicjournals.org/

Caldenby, C. (1994). Universitetet och Staden, White Coordinator Påbygget, Alvesta.

Carrabine, E., Cox, P., Lee, M., Plummer, K \& South, N. (2008). Criminology: A sociological introduction. New York, USA: Routledge, Taylor \& Francis e-Library. www.routledge.com/textbooks/www.eBookstore.tandf.co.uk

Chaliand, G. \& Blin, A. (Eds.) (2007). The History of Terrorism from Antiquity to Al Qaeda USA: University of California Press Berkeley Los Angeles London. www.ucpress.edu.

Common Social Vices In Schools: Causes, Effects \& Solutions (2017). Information Parlour: http://informationparlour.com/ Retrieved November 3.

Ekejiuba, P. (2015).The running of hostels as auxiliary services in University of Benin: Implications for academic studies. African Educational Research Journal Vol. 3(1), pp. 51-54, February 2015 ISSN: 2354-2160. Accessed November 3, 2017.

Holahan, C. J., \& Wilcox, B. L. (1978). "Residential satisfaction and friendship formation in high and low rise student housing: an interactional analysis." Journal of Educational Psychology, 70(2), 237-241.

Hornby (2004): Advance Learners Dictionary. Oxford university press. London.

http://www.google.com/a/nsuk.edu.ng Copyright @ IT Centre, Nasarawa State University, Keffi. Sourced December 30, 2017. 
Ijaiya, Y. (2001). From quality control to quality assurance: A panacea for quality education in Nigerian Schools. In N.A. Nwagwu, E.T. Ehiametalor, M.A Ogunu and M. Nwadiani (Eds.). Current issues in educational management in Nigeria: A publication of the Nigerian Association for Educational Administration and Planning. Benin City: NAEAP pp. 295-303. Retrieved from http://www.academicjournals.org/ November 7, 2017

Information Communication Technology (ICT) Centre, (2017). Nasarawa State University Keffi

Inyang, M. N. (2017). Education and national development: An Appraisal. International Journal of Operational Research in Management, Social Sciences \& Education 3 (1) pp 66-70 ISSN (Print): 2536-6521 ISSN (Online): 2536-653X

Iwerimie-Jaja, D. (2012) Criminology. The study of crime. Oweri, Imo State: Springfield Publishers Ltd Jabar, F.A., Yahya, W.K., Isnani, Z. \& Abu, Z. (2012). An Empirical Study toward Students' Academic Performance and Students' Residential Status. MALAYSIA, Pahang: Bukit Gambang Resort, KONAKA. Accessed November 3, 2017 from https://www.researchgate.net/publication/

List of Nigerian universities http://www.fme.gov.ng/Ministry of Education (Nigeria) Retrieved 2017-11-03.

Merton, R.K. (1938) "Social structure and Anomie theory." The Sociology of Crime and Delinquency. Merton, Robert K. (2010). Encyclopædia Britannica. Encyclopaedia Britannica Student and Home Edition. Chicago: Encyclopædia Britannica.

Moore, R. H. (1976). A review of research on person-environment congruence in Holland's theory of careers. Retrieved December 30, 2017 from www.sciencedirect.com/science/article/

Office of the Dean, School of Post Graduate Studies, Nasarawa State University, Keffi (2018)

Ogeah, F.N. \&Ajalaye, V. (2011). Students' off-campus residence and impact on localities: The case of the University of Benin and Ekosodin village. Global Journal of Social Sciences. 10 (1\&2).

https://www.ajol.info/index.php/gjss/article/ Retrieved November 3, 2017.

Okebukola, P. (200). Principles and Policies Guiding Current Reforms in Nigerian Universities Council for the Development of Social Science Research in Africa JHEA/RESA 4(1) pp. 25-36 (ISSN 0851-7762). Retrieved November 9,2017

Osewa, O. (2017). Hostel or Off-campus, which do you Prefer? Naira land Forum- Education - Nigeria. http://www.nairaland.com/ Retrieved on November 3.

Owolabi, B. O. (2015). The Effects of Students' Housing on Academic Performance at the University of Ibadan in Nigerian. International Journal of Scientific \& Engineering Research 6(3) ISSN 2229-5518. Retrieved November 9 , 2017.

Schudde, L.T. (2011) The Causal effect of campus residency on college student retention. Project MUSE - The Review of Higher Education Volume 34(4), Number 4, pp. 581-610 Retrieved 11/10/2017 from https://muse.jhu.edu/article/439958/

The Nation Nigeria News papers (2017) Curbing campus vices. Retrieved from http://thenationonlineng.net/curbing-campus-vices/ November 3, 2017

Ubong, B. (2007). Hostel accommodation in tertiary education institution in Nigeria: To be or not. Retrieved December 30, 2017 from www.bassoyubing.com/Hostel of 20

Yusuff, O. (2011). Students' access to housing: A case of University Lagos State University students Nigeria. Journal of Sustainable Development 4(2): 107.

Zotorvie, T.J.S. (2017). Students' Accommodation and Academic Performance: The Case of Ho Technical University, Ghana. European Scientific Journal 13(13) ISSN: 1857 - 7881 (Print) e -ISSN 1857- 7431 DOI: 10.19044/esj.2017.v13n13p290 